\title{
The Origin of Hypergamy.
}

A $\mathrm{T}$ a meeting of the Royal Anthropological Institute held on November 9, Mr. S. H. Ray, vicepresident, in the chair, Dr. W. H. R. Rivers read a paper on "The Origin of Hypergamy."

Dr. Rivers said that the term "hypergamy" had been used loosely by both Sir Herbert Risley and Dr. W. Crooke to denote marriage between groups which differ in rank, but for the sake of clearness the term should be confined to those instances in which there was a characteristic difference between the marriage rules for the two sexes. Hypergamy thus understood was that form of marriage in which men mate with women of lower rank than their own, but do not give their women in return, the union of these being confined to men of their own or higher grades. Owing to the fact that women of the highest group can only marry men of their own rank, women of high rank either remain unmarried or the inequality is redressed by the practice of polygyny or by female infanticide. On the other hand, since men of the lowest grade may only marry women of their own rank, while such women are taken by men of a higher group, there is a shortage of women of the lowest grade, and the men must remain unmarried or have recourse to polyandry, or they may seek their wives elsewhere. If the neighbouring communities are hypergamous or endogamous, the only unions open to them will be. with any aboriginal women who may live in the neighbourhood. The practice of hypergamy is not only peculiar to India, but is there almost entirely confined to the Rajputs, or castes, such as the Kulin Brahmans, which have come under Rajput influence. Where the custom occurs among the castes of Bengal, it would seem to have been derived from the Kulins. It appears probable that the Kulin custom can be traced to Rajput influence, as the Kulins are derived from Brahmans who about A.D. 700 came to Bengal from Kanauj, at one time the centre of Rajput rule. Hypergamy also occurs among the Nayars of Malabar, but in this case its relation to the practice in other parts of India is not so clear. One form arises out of their relation with the Nambutiri Brahmans, among whom the rule is that only the eldest son may marry; the other sons contract unions with Navar women. A Nambutiri woman would not be allowed to marry a man, Nayar or other, of a lower caste. The status of the children is determined by the Nayar rule of matrilineal descent. There is no evidence to connect the practice among the Nayars and other cases occurring sporadically in the Madras Presidency with Rajput influence, and it is possible that with them it may have a more ancient history and go back to a remote derivation from the warrior caste.

The institution of hypergamy appears to be a special form of interaction between immigrants into India and the indigenous population, and to be an intermediate stage between the complete fusion which has taken place in such cases in other parts of the world and the segregation which has produced the more characteristic forms of the caste system of India. The development of hypergamy may be referred to three special conditions: (I) The especial strength of a sentiment of the immigrants concerning the union of their women with indigenous men; (2) a short distance of migration, so that the immigrants were accompanied by a relatively large number of women; and (3) the military character of the invaders, which allowed them to obtain indigenous women without giving their own women in return.

An interesting discussion followed the reading of the paper, in which emphasis was laid upon the im. portance of the principles formulated by Dr. Rivers in their bearing upon questions of racial admixture and fusion of language as a result of peaceful penetration or invasion in other parts of the world. Prof. Parsons pointed out that the Saxons had brought a large number of women with them to this country, as was shown by the skeletal remains, whereas the Norsemen who invaded France constituted a male invasion solely, and this probably explained the almost complete substitution of French among them for their own language, the language of the native mothers having prevailed. Mr. Ray pointed out that while the words denoting close family connection in this country were predominantly Saxon, the language of the children contained Celtic elements, as, for example, the word "dad." Prof. C. G. Seligman said that he had found a practice similar to hypergamy among nomad Arab tribes of the Sudan, in which black slaves, the offspring of Arab men and indigenous women, although permitted to hold very high office in the tribe, were not allowed to marry Arab women. Col. Hodgson pointed out that the restriction of marriage to the eldest son also existed among the Kyasths, the reason in this case being that that son was the only true reincarnation of the father, his younger brothers being the "children of sin."

\section{Studies in British Forestry. ${ }^{2}$}

THE Forestry Commission has made a good start, having acquired during the first year of its operations as many as 65,000 acres of land, of which I 500 acres have been planted with trees. During the present year 5900 acres of new plantations are planned. These figures are well ahead of the schedule of the first two years' work which was laid down in the Reconstruction Forestry Sub-Committee Report. This is satisfactory as regards the part played by the State in national afforestation, but we must not forget the work to be done by landowners in replanting the extensive areas which were felled during the war.

1 Forestry Commission. Bulletin No. $x$ : "Collection of Data as to the Rate of Growth of Timber." (To be obtained from the Forestry Commission on sending $4 d$. and a stamp $=$ d addressed envelope.) Bulletin No. 2 : "Survey of Forest Insect Conditions in the British I-les, 1919." (H. M. Stationery Office.) Price is. $6 \%$ net. Bulletin No. $3:$ "Rate of Growth of Conifer in the British Isles." (H.M. Stationery Office.) Price 3s. net. No. 2672 , VOL. IO6]
The Forestry Commission can assist private comprise by money grants for planting, by particulars schemes, and by providing nursery plants at a cheep rate, but it can also stimulate owners to active measures of afforestation by the publication of trustworthy facts and figures concerning all forestry matters. We welcome, then, the three interesting bulletins which have been recently issued. Technical skill in the rearing and planting of trees is not lacking in this country, but much ignorance prevails as to the actual results obtainable by afforestation with different species of trees. Bulletins Nos. I and 3 are concerned mainly with this question, and their perusal will enable owners to deal intelligently with some problems of replanting and afforestation.

A survey for the collection of statistics as to the rate of growth and production of timber in the United Kingdom was carried out officially in $1917-19$, and 